УДК 349.22

DOI https://doi.org/10.32849/2663-5313/2020.2.39

Людмила Могілевсъка, викладач кафедри правоохоронної діяльності та полічіӥстики факультету № 6

Харківського начіонального університету внутрішніх справ

\title{
ДО ПРОБЛЕМИ ВЗАЄМОДІЇ НАЦІОНАЛЬНОЇ ПОЛІЦІЇ 3 ГРОМАДСЬКІСТЮ ТА 3 ІНШИМИ ОРГАНАМИ ДЕРЖАВНОЇ ВЛАДИ У СФЕРІ ЗАБЕЗПЕЧЕННЯ ПРАВ І СВОБОД ДИТИНИ
}

У статті на основі аналізу норм чинного законодавства Украӥни та наукових поглядів учених досліджено проблему взаємодії Національної полічї̈ з громадськістю та іншими органами державної влади у сфері забезпечення прав і свобод дитини. Обгрунтовано, що незалежно від суб'єкта, з яким співпращює полічія, саме взаємодія дає змогу більш оперативно виявити та припинити порушення прав та свобод дитини, що, безперечно, позитивним чином відображається: по-перше, на якості захисту прав та свобод дитини, а по-друге, на іміджі самих органів Начіональної полічії України. Наголошено, що особливу увагу органи прокуратури мають приділяти захисту прав і свобод дітейсиріт та дітей, позбавлених батьківського піклування, дітей-інвалідів, дітей, які виховуються в сім'ях, що перебувають у складних життєвих обставинах, залишених без догляду батьків, переміщених з тимчасово окупованої території України, районів воєнних дій, збройних конфліктів та інших надзвичайних ситуачій. Визначено, що з метою забезпечення прав та свобод дитини Національна полічія України та ї̈ підрозділи мають активно співпрацювати зі звичайними загальноосвітніми навчальними закладами. Така взаємодія пери за все носить суто профілактичний характер та має велике практичне значення: по-перше, для органів Начіональної поліиії, оскільки через відповідну співпрачю вони можуть проводити профілактичні бесіди з учнями щодо їхніх прав та свобод, якими вони можуть користуватись. Крім того, керівництво шкіл може акиентувати увагу правоохоронних органів на тих, учнях, які входять до так званої «групи ризику». По-друге, для керівників та викладачів шкіл, оскільки це полегшує їм роботу з проблемними учнями та розширює іхній кругозір у роботі з дітьми, зокрема у частині дотримання прав та свобод останніх. Зроблено висновок, що в умовах свогодення взаємодія Начіональної поліиії України з громадськістю та іншими органами державної влади у сфері забезпечення прав і свобод дитини є вкрай необхідною. Зазначене пов'язано з тим, що полічія фактично не зможе самостійно виконати покладені на неї обов'язки у иій сфері, що пов'язано зі специфікою роботи з дітьми та їхнім особливим правовим статусом.

Ключові слова: взаємодія, Національна поліція, громадськість, органи державної влади, прокуратура, права і свободи дитини.

Постановка проблеми. Аналіз наукових точок зору та норм чинного законодавства України дає змогу з упевненістю стверджувати, що натепер Національна поліція України є важливим суб'єктом забезпечення прав і свобод дитини. Втім, безспірним $є$ той факт, що поліція не в змозі самостійно вирішити всі наявні проблеми у зазначеній галузі. А тому, здійснюючи свою діяльність у сфері забезпечення прав і свобод дитини, Нацполіція має постійно взаємодіяти 3 громадськістю та 3 іншими органами державної влади у цій сфері, що значною мірою пов'язано із правовим статусом дітей та специфікою роботи 3 ними. Під взаємодією у контексті обраної проблематики слід розуміти спільну взаємоузгоджену діяльність Національної поліції України з громадськістю та іншими органами державної влади, яка спрямована на досягнення єдиної мети - забезпечити належний захист та реалізацію прав і свобод дитини в Україні. Виходячи із вказаного вище, можна зробити висновок, що суб’єкти, 3 якими взаємодіють органи поліції в контексті забезпечення прав та свобод дитини, можна поділити на дві групи: 1) взаємодія 3 громадськістю; 2) з іншими органами державної влади, які відповідно до норм чинного законодавства уповноважені здійснювати свою діяльність у досліджуваній сфері суспільних відносин. А тому дослідження проблеми взаємодії Національної поліції 3 громадськістю та 3 іншими органами державної влади у сфері забезпечення прав і свобод дитини має велике теоретичне та практичне значення. 
Стан дослідження. Варто відзначити, що багато проблем щодо діяльності Національної поліції України у сфері захисту прав та свобод людини вже були у полі зору науковців, зокрема їм приділяли увагу: О.М. Бандурка, О.I. Вінгловська, А.Ю. Ковальчук, І.О. Кресіна, Я.І. Маслова, Л.Л. Тарасенко, Т.Я. Харук, С.I. Шевченко та багато інших. Однак, незважаючи на чималу кількість наукових розробок, у більшості робіт проблема взаємодії Національної поліції з громадськістю та з іншими органами державної влади у сфері забезпечення прав і свобод дитини або не розглядалась взагалі, або ж носила суто поверхневий характер.

Саме тому мета статті - надати характеристику взаємодії Національної поліції з громадськістю та з іншими органами державної влади у сфері забезпечення прав і свобод дитини.

Виклад основного матеріалу. Враховуючи особливості діяльності Нацполіції та специфіку правового статусу дитини в Україні та всьому світі, перш за все необхідно приділити увагу взаємодії вказаного центрального органу виконавчої влади 3 громадськістю. Можна 3 упевненістю констатувати, що в сучасній соціально-спрямованій та демократичній державі взаємодія 3 громадськістю будь-якого органу державної влади має вагоме значення як для держави загалом, так і для суспільства і кожного громадянина зокрема. I взаємодія з Нацполіцією у цьому контексті не $€$ винятком. Натепер важливими є такі завдання з активізації взаємодії між органами Національної поліції України і громадськістю [1, с. 4], як: підвищення авторитету й довіри населення до органів Національної поліції України; покращення стану комунікативної та загальної культури працівників Нацполіції; сприяння об'єктивному інформуванню населення про діяльність працівників правоохоронних органів за допомогою засобів масової інформації; ретельна перевірка фактів і матеріалів, які публікуються чи демонструються в мас-медіа; створення позитивного іміджу шляхом підвищення рівня професійної компетентності та покращення результатів діяльності працівників Національної поліції України; забезпечення безпосереднього діалогу між поліцією та населенням (громадськими об'єднаннями, профспілками, асоціаціями, організаціями, підприємствами) під час особистих зустрічей громадян із керівниками підрозділів ОВС, найкращими працівниками, персоналом служби громадської безпеки, які забезпечують правопорядок на конкретній території [1, с. 4].
Таким чином, вдосконалення взаємодії поліції з населенням - це необхідна умова існування довіри громадян до правоохоронних органів, а також і до влади загалом; аналіз і використання зарубіжного досвіду участі населення у правоохоронній діяльності це дієвий інструмент якісного покращення співробітництва поліції і громадськості, реальна можливість підвищення ефективності роботи поліції через впровадження в роботу правоохоронних органів моделей діяльності поліції зарубіжних країн із використання консультативного механізму та співпраці з населенням щодо забезпечення громадського порядку і це нагальна потреба теперішнього часу; $є$ необхідність у розробці та прийнятті нормативних документів, які б регламентували цей аспект правоохоронної діяльності як на державному, так і на галузевому рівнях; необхідно передбачити правове закріплення видів морального та матеріального заохочення членів громадських формувань, а також громадян, які беруть індивідуальну участь у правоохоронній діяльності [2, c. 165].

Отже, весь наведений вище матеріал дає змогу говорити про те, що взаємодія Національної поліції України з громадськістю щодо забезпечення прав та свобод дитини має велике практичне значення, адже: по-перше, «зближає» органи поліції з громадськістю, тим самим підвищуючи рівень довіри останніх до перших; по-друге, дає змогу Нацполіції більш глибоко з'ясувати проблеми, які існують у досліджуваній сфері. Якщо говорити більш детально, то ефективна взаємодія Національної поліції з громадськістю дасть змогу:

а) для громадян: забезпечити більшу поінформованість усіх громадян, у тому числі і дітей про їхні права та свободи, якими вони можуть вільно користуватись відповідно до чинного законодавства України; громадяни можуть більш оперативно повідомляти поліцію про випадки порушення прав та свобод дитини; через взаємодію громадськість здійснює контроль за діяльністю поліції. Таким чином, є можливість надати об'єктивну оцінку роботі органів Національної поліції України як з боку населення країни, так і з боку керівництва держави;

б) для Національної поліції України: більш оперативно визначати причини вчинення правопорушень щодо дитини, що дадуть змогу надалі завчасно попереджати їх виникнення; співпрацюючи з громадою, поліція має можливість підвищувати обізнаність мешканців про свою роботу (наприклад, про межі компетенції поліцейських або про альтернативні шляхи вирішення проблем). А це дасть змогу в майбутньому зменшити наван- 
таження на патрульну поліцію; дасть змогу заручитись підтримкою населення, а це, апріopi, є важливим превентивним заходом щодо вчинення правопорушень стосовно дитини; виявити слабкі місця у своїй діяльності щодо забезпечення прав та свобод дитини, а тому прийняти ефективні управлінські рішення спрямовані на вирішення власних проблем.

Переходячи до наступної групи суб'єктів, з якими взаємодіє Національна поліція у контексті забезпечення прав та свобод, окремо слід вказати прокуратуру України та іiі органи. Так, насамперед слід відзначити, що відповідно до Наказу ГПУ «Про організацію діяльності органів прокуратури щодо захисту прав і свобод дітей» від 06 грудня 2014 року [3] пріоритетними напрямами представництва інтересів дітей та держави у суді визначити захист у сферах: охорони життя і здоров'я дітей, їхніх прав на освіту, відпочинок та змістовне дозвілля; опіки, піклування, усиновлення дітей; майнових та житлових прав дітей, їх соціального забезпечення; прав неповнолітніх на працю та працевлаштування; попередження та захисту від усіх форм насильства; користування та розпорядження органами виконавчої влади, органами місцевого самоврядування майном, землями навчальних, оздоровчих, лікувальних, а також інших закладів для дітей; використання бюджетних коштів, спрямованих на реалізацію програм та заходів з охорони дитинства, закупівлю відповідних товарів, робіт і послуг. Особливу увагу органи прокуратури мають приділяти захисту прав і свобод дітей-сиріт та дітей, позбавлених батьківського піклування, дітей-інвалідів, дітей, які виховуються в сім'ях, що перебувають у складних життєвих обставинах, залишених без догляду батьків, переміщених з тимчасово окупованої території України, районів воєнних дій, збройних конфліктів та інших надзвичайних ситуацій [3].

Що ж стосується безпосередньо взаємодії Національної поліції з органами прокуратури, то така взаємодія найчастіше виникає безпосередньо у разі вчинення правопорушення або стосовно дитини, або ж самою дитиною. Так, відповідно до «Інструкції з організації роботи підрозділів ювенальної превенції Національної поліції України» від 19 грудня 2017 року підставою для прийняття підрозділом ЮП дитини на облік є письмове повідомлення слідчого, прокурора про вручення дитині повідомлення про підозру в учиненні кримінального правопорушення. Або ж дитину може бути знято з відповідного обліку у разі письмового повідомлення слідчого, прокурора про зняття з дитини підозри в учиненні кримінального правопорушення [4].
Окремої уваги заслуговує взаємодія Національної поліції України 3 органами державної влади, органами місцевого самоврядування, закладами та установами під час забезпечення соціального захисту дітей, які перебувають у складних життєвих обставинах, у тому числі таких, що можуть загрожувати їхньому життю та здоров'ю [5]. Складні життєві обставини, в яких перебуває дитина, нормами чинного законодавства визначаються як умови, що негативно впливають на життя дитини, стан її здоров'я та розвиток (інвалідність, тяжка хвороба, безпритульність, перебування у конфлікті із законом, залучення до найгірших форм дитячої праці, залежність від психотропних речовин, інші види залежності, жорстоке поводження, зокрема домашнє насильство, у тому числі у разі, коли кривдником є дитина, ухиляння батьків, осіб, які їх замінюють, від виконання своїх обов'язків, обставини стихійного лиха, техногенних аварій, катастроф, воєнних дій чи збройних конфліктів тощо), установлені за результатами оцінки потреб дитини [5].

Взаємодія Нацполіції із зазначеними вище суб'єктами в рамках цієї проблематики передбачає, що:

- юридичні та фізичні особи, яким стало відомо про дитину, яка постраждала від жорстокого поводження або життю чи здоров'ю якої загрожує небезпека, зобов'язані забезпечити надання екстреної медичної допомоги, невідкладно звернутися до органів Національної поліції або підпорядкованого підрозділу територіального органу ДСНС для організації її подальшого захисту у разі, коли дитина потребує медичної допомоги;

- органи Національної поліції зобов'язані протягом доби поінформувати службу у справах дітей районної, районної у мм. Києві та Севастополі держадміністрації, виконавчого органу міської, районної у місті (у разі утворення) ради, сільської, селищної ради, об'єднаної територіальної громади (далі служба у справах дітей) про виявлену дитину для організації її соціального захисту;

- суб'єкти виявлення та/або організації соціального захисту дітей незалежно від повноважень зобов'язані у разі, коли у зверненні стосовно дитини вбачається склад адміністративного правопорушення чи 3лочину, невідкладно повідомити органам Національної поліції. Невідкладно у строк, що не перевищує однієї доби, повідомити (в тому числі за допомогою телефонного зв'язку) про дитину, яка постраждала від жорстокого поводження або життю чи здоров'ю якої загрожує небезпека, представнику служби у справах дітей за місцем їі виявлення для організації заходів невідкладного реагу- 
вання, в тому числі надання послуги з кризового та екстреного втручання, та органам Національної поліції;

- у разі надходження повідомлення про дитину, яка постраждала від жорстокого поводження або життю чи здоров'ю якої загрожує небезпека, служба у справах дітей разом з уповноваженим підрозділом органу Національної поліції, фахівцем із соціальної роботи, представниками закладу охорони здоров'я невідкладно проводить оцінку рівня безпеки дитини [5].

Окремо слід вказати, що відповідно до «Порядку взаємодії органів державної влади, органів місцевого самоврядування, закладів та установ під час забезпечення соціального захисту дітей, які перебувають у складних життєвих обставинах, у тому числі таких, що можуть загрожувати їх життю та здоров'ю», що організація допомоги дітям, які постраждали від жорстокого поводження, життю або здоров'ю яких загрожує небезпека, органами Національної поліції передбачає: 1) цілодобове прийняття інформації, в тому числі усної, про дітей, яким загрожує небезпека, працівниками всіх підрозділів і вжиття невідкладних заходів реагування; 2) проникнення до житла чи іншого приміщення (володіння) особи без її згоди або вмотивованого рішення суду у невідкладних випадках, пов'язаних 3 виникненням безпосередньої загрози життю або здоров'ю дитини, або за наявності підстав вважати, що така загроза існує; 3) за наявності ознак кримінального правопорушення - внесення відповідних відомостей до Єдиного реєстру досудових розслідувань, у зв'язку з чим вживаються подальші слідчі (розшукові) дії [5].

В окрему підгрупу, з якими взаємодія Національна поліція України, слід виділити органи, які визначені Законом України «Про органи і служби у справах дітей та спеціальні установи для дітей» від 24 січня 1995 року. Зокрема, до них віднесено: школи соціальної реабілітації та професійні училища соціальної реабілітації органів освіти; центри медико-соціальної реабілітації дітей закладів охорони здоров'я; спеціальні виховні установи Державної кримінально-виконавчої служби України; притулки для дітей; центри соціально-психологічної реабілітації дітей; соціально-реабілітаційні центри (дитячі містечка) [6]. Слід ще раз підкреслити, що відповідно до зазначеного нормативно-правового акта саме Національна поліція України та її підрозділи визнаються одними із ключових суб'єктів забезпечення й захисту прав та свобод дитини в Україні. Аналіз положень вказаного вище Закону дає змогу констатувати, що поліція в рамках взаємодії з іншими органами і службами у справах дітей має: проводити роботу щодо запобігання правопорушенням дітей серед дітей, які перебувають у центрах медико-соціальної реабілітації дітей закладів охорони здоров'я, спеціальних виховних установах Державної кримінально-виконавчої служби України, притулках для дітей тощо. Крім того, поліція безпосередньо взаємодіє із керівництвом указаних вище установ 3 метою їх консультування та підтримки у роботі зі «складними» дітьми; розшукувати дітей, що зникли, дітей, які залишили сім'ї, навчальновиховні заклади (бродяжать) та спеціальні установи для дітей; отримувати від підприємств, установ та організацій незалежно від форм власності відомості, необхідні у зв'язку 3 матеріалами про правопорушення, що перебувають у їх провадженні; спільно із вказаними суб'єктами здійснювати згідно з чинним законодавством гласні та негласні оперативно-розшукові заходи з метою розкриття кримінальних правопорушень, вчинених дітьми або за їх участю; тощо [7].

Із зазначеного вище витікає, що поліція активно та на постійній основі взаємодіє з органами і службами у справах дітей та спеціальними установами для дітей.

Наостанок хотілося б звернути увагу на те, що з метою забезпечення прав та свобод дитини Національна поліція України та ï підрозділи мають активно співпрацювати зі звичайними загальноосвітніми навчальними закладами. Така взаємодія перш за все носить суто профілактичний характер та має велике практичне значення: по-перше, для органів Нацполіції, оскільки через відповідну співпрацю вони можуть проводити профілактичні бесіди з учнями щодо їхніх прав та свобод, якими вони можуть користуватись. Крім того, керівництво шкіл може акцентувати увагу правоохоронних органів на тих учнях, які входять до так званої «групи ризику». По-друге, для керівників та викладачів шкіл, оскільки це полегшує їм роботу з проблемними учнями та розширює їхній кругозір у роботі з дітьми, зокрема у частині дотримання прав та свобод останніх.

\section{Висновок}

Завершуючи наукове дослідження, слід констатувати, що в умовах сьогодення взаємодія Національної поліції України з громадськістю та з іншими органами державної влади у сфері забезпечення прав і свобод дитини є не просто важливим напрямом ї діяльності, а й є вкрай необхідною. Зазначене пов'язано з тим, що поліція фактично не зможе самостійно виконати покладені на неї обов'язки у цій сфері, що пов'язано зі спе- 
цифікою роботи з дітьми та їхнім особливим правовим статусом. Крім того, незалежно від суб'єкта, з яким співпрацює поліція, саме взаємодія дає змогу більш оперативно виявити та припинити порушення прав та свобод дитини, що, беззаперечно, позитивним чином відображається: по-перше, на якості захисту прав та свобод дитини, а по-друге, на іміджі самих органів Національної поліції України.

\section{Список використаних джерел:}

1. Бесчастний В., Гребеньков Г. Взаємодія міліції й населення як стратегічний напрям діяльності органів правопорядку. Biче. 2013. № 12. C. $2-5$.

2. Шевченко С.I. Особливості взаємодії Національної поліції з громадськістю в процес забезпечення публічного порядку. Науковий вісник публічного та приватного права. Вип. 6. Т. 2 . 2017. C. $162-168$.

3. Про організацію діяльності органів прокуратури щодо захисту прав і свобод дітей : Наказ Генеральної прокуратури України від 06.12.2014 № 16гн. URL: https://zakon.rada. gov.ua/rada/show/v0016900-14/conv.

4. Про затвердження Інструкції з організації роботи підрозділів ювенальної превенції Національної поліції України : Наказ Міністерства внутрішніх справ України 19.12.2017 № 1044. URL: https://zakon.rada.gov.ua/laws/show/ z0686-18/conv.

5. Порядок взаємодії органів державної влади, органів місцевого самоврядування, закладів та установ під час забезпечення соціального захисту дітей, які перебувають у складних життєвих обставинах, у тому числі таких, що можуть загрожувати їх життю та здоров'ю : Постанова Кабінету Міністрів України від 3 жовтня 2018 p. № 800. URL: https://zakon.rada.gov.ua/ laws/show/800-2018-п/conv.

6. Петров В.Г. Форми адміністративноправової діяльності правоохоронних органів. Наукові пращі НУ ОЮА. С. 442-447.

7. Про органи і служби у справах дітей та спеціальні установи для дітей : Закон України від 24 січня 1995 року № 20/95-BP. URL: https://zakon.rada.gov.ua/laws/show/20/ 95-\%D0\%B2\%D1\%80.

In the article, on the basis of the analysis of norms of the current legislation of Ukraine and scientific vieves of scientists, the problem of interaction of the National Police with the public and with other state authorities in the sphere of ensuring the rights and freedoms of the child is investigated. It is justified that regardless of the subject with which the police cooperate, the interaction itself allows to detect and stop violations of the rights and freedoms of the child more quickly, which undoubtedly positively reflects: first, the quality of protection of the rights and freedoms of the child, and second, on the image of the bodies of the National Police of Ukraine. It is emphasized that the special attention should be paid by the Prosecutor's Office to the protection of the rights and freedoms of orphans and children deprived of parental care, children with disabilities, children being raised in families in difficult life circumstances, left unattended by parents displaced from temporarily occupied territory of Ukraine, areas of hostilities, armed conflicts and other emergencies. It was determined that in order to ensure the rights and freedoms of the child, the National Police of Ukraine and its units should actively cooperate with the usual general educational institutions. Such interaction is, first and foremost, of a purely preventative nature and of great practical importance: first, for the National Police bodies, because through appropriate cooperation they can conduct preventive discussions with students about their rights and freedoms, which they can enjoy. In addition, school management can focus law enforcement on those students who are part of the so-called "at-risk" group. Secondly, for school principals and teachers, as it facilitates their work with troubled students and broadens their outlook on working with children, particularly in respect of the rights and freedoms of the latter. It is concluded that in the conditions of today the interaction of the National Police of Ukraine with the public and with other state authorities in the sphere of ensuring the rights and freedoms of the child is extremely necessary. This is due to the fact that the police will not, in fact, be able to carry out their duties in this field on their own, which is related to the specificity of working with children and their special legal status.

Key words: interaction, National Police, public, public authorities, prosecutor's office, rights and freedoms of the child. 